\title{
The trinity of the cortical actin in the initiation of HIV-1 infection
}

\author{
Mark Spear, Jia Guo and Yuntao Wu*
}

\begin{abstract}
For an infecting viral pathogen, the actin cortex inside the host cell is the first line of intracellular components that it encounters. Viruses devise various strategies to actively engage or circumvent the actin structure. In this regard, the human immunodeficiency virus-1 (HIV-1) exemplifies command of cellular processes to take control of actin dynamics for the initiation of infection. It has becomes increasingly evident that cortical actin presents itself both as a barrier to viral intracellular migration and as a necessary cofactor that the virus must actively engage, particularly, in the infection of resting CD4 blood T cells, the primary targets of HIV-1. The coercion of this most fundamental cellular component permits infection by facilitating entry, reverse transcription, and nuclear migration, three essential processes for the establishment of viral infection and latency in blood T cells. It is the purpose of this review to examine, in detail, the manifestation of viral dependence on the actin cytoskeleton, and present a model of how HIV utilizes actin dynamics to initiate infection.
\end{abstract}

Keywords: HIV-1, gp120, Nef, Actin, Cofilin, LIMK1, Arp2/3, CD4, CXCR4, Chemokine, Chemotaxis

\section{Review \\ Background}

The cytoskeleton is a dynamic structure composed of microfilaments (filamentous actin or F-actin), intermediate filaments, and microtubules that are mainly responsible for defining cell shape, mediating motility, and transporting macromolecules and organelles. The actin cytoskeleton, in particular, has been shown to be the driving force for cell motility and migration [1], and is involved in multiple cellular processes in the host immune response [2,3]. As an integral component of intracellular molecular networks, the actin cytoskeleton is also a target for pathogens, as originally recognized in studies of the human pathogens Listeria monocytogenes [2,3] and vaccinia virus [4]. Complex viruses such as vaccinia virus (200 kb dsDNA genome, encoding approximately 250 genes) or baculovirus (130 kb dsDNA genome, encoding approximately 150 genes) utilize dedicated viral proteins such as A36R and P78/83 to hijack the cellular actin polymerization process to propel essential viral activities $[4,5]$. In vaccina viral infection, the virus mimics normal

\footnotetext{
*Correspondence: ywu8@gmu.edu

National Center for Biodefense and Infectious Diseases, Department of

Molecular and Microbiology, George Mason University, Manassas, VA 20110,
} USA

\section{Biomed Central}

cellular signaling pathways to mediate actin-based motility for spreading between cells. This is achieved through tyrosine phosphorylation of A36R that recruits host $\mathrm{N}$ Wiskott-Aldrich syndrome protein (N-WASP) to the site for actin assembly [4]. In baculovirus, actin-based viral motility is required for viral intracellular migration and nuclear entry early in the infection process and viral spread towards the end of the viral life cycle [6]. Remarkably, to trigger actin polymerization in the nucleus, the virus translocates the host Arp $2 / 3$ complex into the nucleus where it is activated by P78/83, a viral mimic of the host WASP protein [5]. However, small viruses such as HIV (9 kb ssRNA genome, encoding 9 genes) may not have proteins with such a high specificity for the actin network. It remains unknown if any of the HIV-encoded essential or accessory proteins has a dedicated role for utilizing the actin network.

From a historical perspective, early indications that HIV may interact with cytoskeletal elements came from several studies. Hottiger et al. described a potential interaction between actin and either the large subunit of HIV-1 reverse transcriptase or Pol polyprotein precursor [7]. Rey et al. described cofractionation and interaction of HIV Gag with F-actin [8], which was later mapped to the Gag nucleocapsid (NC) domain [9-11]. HIV integrase and Nef 
were also found to bind to actin [12-14]. However, these and similar findings were not given sufficient attention for several reasons: the degree to which these interactions were specific was uncertain, as actin can interact nonspecifically with many proteins; secondly, the lack of a clear mechanistic process by which actin could contribute to HIV infection may have lessened overall interest in the role of the cytoskeleton; and, last but not least, targeting actin as an antiretroviral strategy is typically viewed as problematic since targeting fundamental cellular elements would result in severe cytotoxicity. As such, the therapeutic applicability of these findings was questionable.

On the other hand, there were some indications that interacting with the actin cytoskeleton may not be so critical for the virus. It has been known that pseudotyping HIV particles with the vesicular stomatitis virus glycoprotein (VSV-G) can generate highly infectious particles in the laboratory [15]. VSV-G pseudotyping mediates viral entry through endocytosis, circumventing the viral receptors and the actin cortex. These results suggest that for HIV, interacting with the cortical actin may be unnecessary and avoidable, as least at postentry steps in transformed cells. However, two pieces of evidence suggest that these observations may not reflect the genuine cellular environment that the virus encounters in vivo. Firstly, the HIV Nef protein, a critical factor involved in HIV pathogenesis, no longer plays a role during VSV-G-pseudotyped virus infection of target cells [15-17]. Coincidentally, it was found that treatment of cells with actin inhibitors also eliminated Nef-mediated enhancement of viral infectivity [18]. These results suggest that at least one viral protein, Nef, may need the involvement of actin to facilitate viral infection and pathogenesis. Secondly, it was recently demonstrated by two independent laboratories that the VSV-G-pseudotyped virus, although highly infectious for transformed cells, is not capable of infecting resting CD4 $\mathrm{T}$ cells, the primary targets of HIV infection $[19,20]$. The VSV-G-pseudotyped virus was either incapable of entering resting CD4 T cells [20] or was destroyed in the endocytic pathway within 1-2 days following entry [19]. If the endocytic pathway [21] is defective in resting $\mathrm{T}$ cells $[19,20]$, HIV envelope-mediated membrane fusion would directly deliver the viral core in front of the cortical actin [22-26]; an encounter and engagement with the cortical actin is unavoidable, either actively or passively.

Cortical actin dynamics in $\mathrm{T}$ cells are normally controlled by chemokine receptor binding and signal transduction [1]. The fact that HIV selects two chemokine receptors, CCR5 and CXCR4, as the main entry coreceptors implies an urgent need for the virus to engage the chemotactic process to initiate infection [19]. This has been explicitly demonstrated recently in HIV-1 latent infection of resting CD4 $\mathrm{T}$ cells $[27,28]$. In this process, HIV utilizes gp120 to trigger the activation of actin regulators such as cofilin and the LIM domain kinase 1 (LIMK1) to increase actin dynamics $[27,28]$. It has become evident that a dynamic cytoskeleton is important for viral entry, postentry DNA synthesis, and nuclear migration in resting $\mathrm{T}$ cells [19,27-30]. These recent studies have rekindled an interest in the role of the actin cytoskeleton in HIV biology and in viral pathogenesis [31-35]. It is the purpose of this review to integrate recent findings with the scattered pieces of data from the past, and to provide a prototype model to facilitate our understanding of this complicated process. In addition, the pathogenic implications of HIV hijacking host actin activity in blood CD4 $\mathrm{T}$ cells will also be discussed in this review.

\section{Role of actin in HIV-1 entry}

HIV entry into target cells requires serial engagement of the primary viral receptor, CD4 [36-41], and coreceptor, CXCR4 [42] or CCR5 [43-48]. This binding event ultimately culminates in viral fusion, wherein the viral core is deposited into the cytoplasmic compartment. A debatable question is to what extent cellular factors determine the outcome of viral receptor/coreceptor engagement. Lapham et al. [49] and others [50-52] produced some of the first data indicating that $\mathrm{CD} 4 /$ coreceptor colocalization at the cell surface is an active process. Specifically, the association of CD4 and the coreceptors is increased upon gp120 binding in $\mathrm{T}$ cells or macrophages. It was also speculated that this association might occur in membrane microdomains [49]. Ugolini et al. observed that CD4/CXCR4 colocalization was increased in response to HIV-1 soluble gp120 treatment [53]. However, this response to gp120 treatment was not experimentally correlated with any infection process, and, as such, its contribution to HIV entry is rather speculative. In addition to receptor colocalization, there is growing evidence indicating that viral entry may be dependent on the actin cytoskeleton as well as dynamic inputs associated with CD4 and coreceptor signal transduction [27,28,53-59]. However, the modeling of an entry requirement for active receptor clustering and receptor signaling must take into account existing evidence on the constitutive association and juxtaposition of CD4 with CCR5 or CXCR4 in the absence of viral binding [49,53,60-63]. Xiao et al. described a constitutive association between CD4 and CCR5 or CXCR4 in cell lines, primary $\mathrm{T}$ cells and macrophages [61], but did not observe a significant increase in CD4/CCR5 coimmunoprecipitation upon gp120 binding [61]. This result was corroborated by a fluorescent resonance energy transfer (FRET) study by Toth et al., showing that CD4 and CXCR4 are constitutively associated to a significant extent on the cell surface, and this interaction is not altered by gp120 binding [64]. Similarly, Singer et al. 
observed a constitutive association between CD4 and CXCR4 or CCR5 on microvilli in PBMC-derived macrophages and $\mathrm{T}$ cells [62]. Immuno-gold electron microscopy showed that CD4 and coreceptors exist as homogenous microclusters that are typically within $100 \mathrm{~nm}$, or one viral diameter, of each other [62]. These findings were again supported by a Fluorescence Recovery After Photo Bleaching (FRAP) study performed by Baker et al., who described a constitutive association of CD4 with multiple CCR5 at the plasma membrane [63]. From these studies, a question arises as to why HIV requires an active process to cocap receptors when these molecules are already abundantly associated. An explanation given by Baker et al. is that although the basal CD4-CCR5 interaction is maximal, the addition of gp120 brings the two receptors closer [63]. This process may be energy-dependent and require active participation of other cellular components [65]. Indeed, it has been suggested that an active infection process requires clustering of multiple gp120 with multiple CD4 and coreceptors [61,66-69]. The recruitment of the gp120-CD4coreceptor complex is believed to occur mainly in lipid rafts [70-74]. Nevertheless, controversies exist regarding whether lipid raft localization of CD4 and the receptors is necessary for entry and productive viral replication $[75,76]$. Regardless of its virological significance, CD4binding beads induced lipid raft recruitment of CXCR4, which was suggested to be actin-dependent as cytochalasin D (CytoD) partially inhibited CXCR4 clustering [74]. This observation seems to resonate with an earlier observation by Iyenger et al. [54], showing that HIV-1 entry can be inhibited by treatment with CytoD. Specifically, CytoD treatment prevents gp120-induced CD4/ CXCR4 colocalization [54]. A remaining issue with the study is that it is not clear why actin needs to be involved when CD4 and CXCR4 are naturally associated in most cases. In addition, it is unknown whether actin is actively involved in driving the receptor clustering process or actin activity is simply an outcome following receptor clustering and signaling.

Binding of HIV particles to resting CD4 T cells was shown to trigger transient actin polymerization [27,28,77]. Vorster and Guo et al. further identified that the actin polymerization process is mediated through transient activation of the LIM Domain Kinase 1, LIMK1, a cellular serine/threonine kinase responsible for phosphorylation and inactivation of the actin-depolymerizing factor, cofilin [28]. Intriguingly, the signaling appears to be transduced sequentially from two sources, one from CD4 and one from CXCR4 [28]. Indeed, it has been estimated that gp120 engagement of CD4 only lasts for about $0.2 \mathrm{~s}$ [78], whereas fusion takes a much longer time to occur and complete [79]. Thus, gp120 may use both CD4 and CXCR4 to initiate signaling to sustain actin activity for successful fusion. Vorster and Guo et al. have suggested that this actin polymerization process is required to block the internalization of CXCR4 following gp120 binding, as shRNA knockdown of LIMK1 decreases the cortical actin density and causes a significant increase in the rate of CXCR4 internalization [28]. These results suggest a model in which actin is mainly involved in the stabilization of the gp120-CD4-CXCR4 complex for fusion rather than to promote the initial receptor migration and colocalization upon gp120 binding. Consistent with this mode of action, treatment of cells with CytoB inhibited fusion mediated by the CD4-independent gp120 [80], suggesting that steps sensitive to the actin inhibitor may not involve CD4 binding or CD4-CXCR4 clustering. Additionally, in HIV gp120-mediated cell-cell fusion, blocking Abl-mediated actin activity arrested fusion at the hemifusion step [59], suggesting again that the steps affected by actin dynamics are directly related to the fusion process and, more specifically, the formation of the fusion pore. In a singlemolecule analysis of gp120 interaction with CD4 and CCR5, it was found that only those CCR5 receptors in close proximity to CD4 can be engaged, since this engagement has to occur very fast when gp120 is still attached to CD4 [78]. This spatial and temporal constraint likely excludes an active role of actin activity in receptor clustering and colocalization because of the relatively slower pace of HIV-mediated actin dynamics. Thus, gp120-mediatd actin activity likely plays several key roles following receptor clustering: (1) to provide a physical support to stabilize the large gp120-CD4-coreceptor aggregates on the plasma membrane; (2) to block immediate coreceptor internalization to give sufficient time for fusion to occur and complete; and (3) to prolong coreceptor signaling for priming post entry events.

The direct signaling pathway regulating this virusmediated actin process has been partially mapped by Vorster and Guo et al. to be the Rac1-PAK1/2-LIMKCofilin pathway in resting CD4 T cells [28]. Consistently, kinases such as IL-2-inducible T-cell Kinase (ITK), a tyrosine kinase required for SDF-1-mediated actin polarization and Rac activation, has been shown to be required for HIV entry [81]. Treatment of Jurkat T cells with gp120 leads to a low, but reproducible level of ITK activation [81], which can be inhibited by ITK inhibitors or siRNA knockdown of ITK. In ITK knockdown T cells, the actin polymerization induced by gp120-coated beads was also impaired and this correlates with the decreases in viral entry [81].

Rac1 activation has also been observed during gp120mediated cell-cell fusion between human astroglioma U87 cells and monkey BSC40 cells [57]. Expression of dominant-negative mutant of RacN17, but not Cdc42N17 or RhoN19, eliminated syncytium formation [57]; Rac activation was also inhibited by a CCR5 antagonist [57]. 
These results suggest that CCR5-derived signal transduction, resulting in the activation of Rac, is required for gp120-mediated cell-cell syncytium formation. Harmon et al. further studied multiple signaling molecules in U87 cells and suggested that Goq, but not Goi or Gos, may be required for cell-cell fusion [58]. This process may involve calcium mobilization [82] and actin regulators such as Arp2/3, as cell-cell fusion can be inhibited either by siRNAs or inhibitors of upstream regulators [59]; though, an early study found that Arp2/3 inhibition, which inhibited HIV infection, did not impact cell-cell fusion [83]. These studies emphasized the complexity of the signaling network regulating actin dynamics during cell-cell syncytium formation. They also greatly expanded the scope for examining possible signaling requirements for viral entry. It is imperative to test whether similar molecules are indeed activated and specifically involved in HIV entry into its natural target cells.

In addition to direct actin regulators, recent studies have also implicated a number of actin-binding adaptor proteins and crosslinkers. For instance, Jiménez-Baranda et al. identified filamin-A as a cofactor for HIV entry [55]. Filamin-A, an actin-crosslinker and adaptor, was also shown to bind CD4, CCR5, and CXCR4. The authors concluded that filamin-A might be required for stability of the fusion complex. Similarly, Naghavi et al. identified moesin as a cellular factor whose overexpression blocks HIV and MLV infection [84]. Moesin belongs to the Ezrin-RadaxinMoesin (ERM) family of proteins that act as crosslinkers between the plasma membrane and actin filaments and are involved in actin-directed signal transduction. Intriguingly, siRNA knockdown of moesin resulted in enhanced infection [84]. This seems to be consistent with the proposal that the cytoskeleton itself is a barrier for viral infection, and slightly disrupting the stability of actin network through actin modulators or spinoculation enhances viral infection [27-29]. Barrero-Villar et al. further studied the role of ERM proteins in HIV infection, and suggested that binding of gp120 to CD4 alone increases ezrin and moesin phosphorylation that might be involved in active receptor clustering [56]. In addition, siRNA knockdown of moesin, but not ezrin, resulted in an inhibition of infection. Once again, this phenomenon was attributed to an effect in receptor clustering and entry; specifically, that the association and clustering of CD4/ CXCR4 induced by gp120 requires moesin-mediated anchoring of actin to the plasma membrane. Nevertheless, moesin knockdown-mediated HIV inhibition was in contrast to the enhancement observed by Naghavi et al. [84]. This difference could result from different cell lines used or the degrees of siRNA silencing that may affect viral processes differently.

In summary, from the studies discussed above, we propose a prototype model in which the role of actin dynamics in HIV entry is described in Figure 1A to 1C: (1) binding of HIV gp120 to target $\mathrm{T}$ cells initiates a transient course of actin polymerization which is mediated through CD4/CXCR4 signal transduction that activates Pyk2, ITK and downstream Rac1, PAK1/2, LIMK1 and cofilin. (2) In the meantime, CD4 signaling or CD4/ CXCR4 signaling also activates actin-anchoring proteins, such as moesin and filamin-A, to anchor F-actin to the plasma membrane and to CD4 and CXCR4. (3) Actin polymerization provides a physical support to stabilize the large gp120-CD4-CXCR4 aggregates on the plasma membrane; (4) F-actin also functions to block immediate CXCR4 internalization to give sufficient time for fusion to occur and complete. (5) Additionally, actin-supported stability of the gp120-CD4-CXCR4 complex may prolong coreceptor signaling for priming postentry events.

\section{Role of actin in HIV-1 postentry DNA synthesis}

Following viral fusion and entry, HIV goes through the processes of uncoating and reverse transcription. The

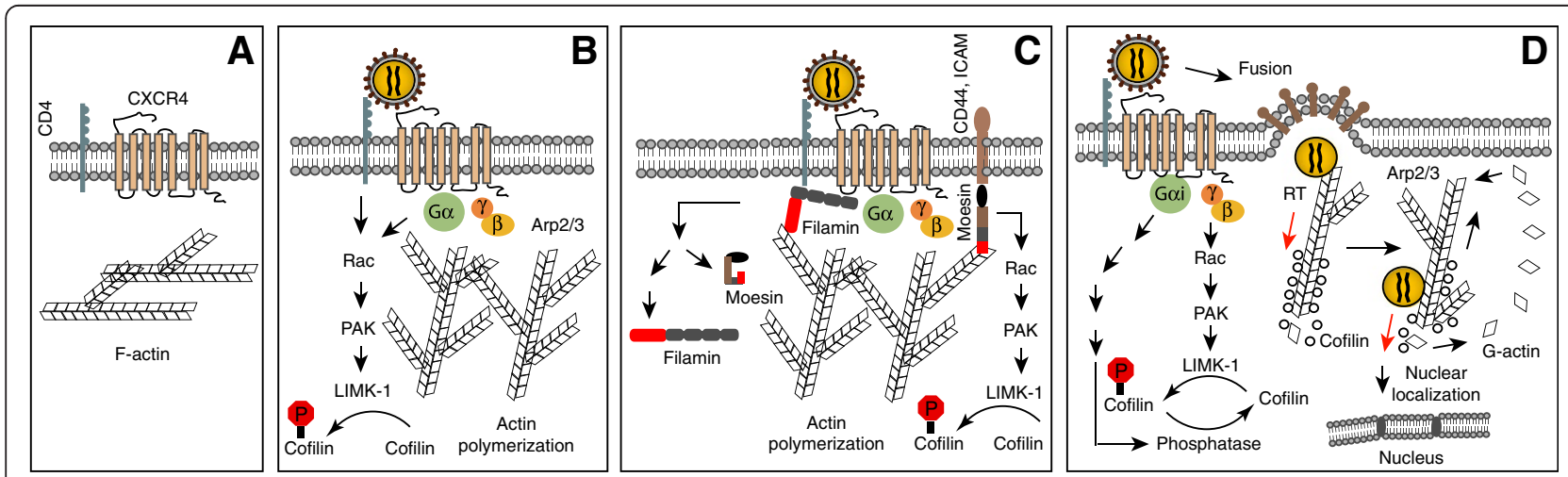

Figure 1 Model of actin dynamics in HIV-1 infection of T cells. Binding of gp120 to CD4 T cells activates Rac-PAK-LIMK-cofilin pathway, triggering early actin polymerization, transiently blocking CXCR4 internalization. Actin-anchoring proteins such as moesin and filamin-A may also serve to anchor the cortical actin to the plasma membrane to facilitate fusion. Following entry, the viral preintegration complex is directly anchored onto the cortical actin for reverse transcription and intracellular migration, which is promoted by cofilin-mediated actin treadmilling. 
involvement of the actin cytoskeleton in viral postentry steps, particularly in the process of reverse transcription, remains poorly characterized. Early indications that components of HIV particles may interact with the cytoskeleton came from studies in 1992 by Arthur et al. who identified actin, among other cellular proteins, in virions collected from sucrose gradient centrifugation [85]. Ott et al. also found three types of actin-related factors present inside HIV virions in various molar ratios to HIV Gag: actin (10-15\%), ezrin and moesin (2\%), and cofilin $(2-10 \%)$ [86,87]. The functional significance of the virion-incorporation of these proteins is unknown, although Wilk et al. demonstrated that the packaged actin filaments are specifically associated with the nucleocapsid (NC) [11]. Through various screening strategies such as yeast two-hybrid system, several other viral proteins have also been found to interact with actin. These include the large subunit of the reverse transcriptase [7], the integrase [13], Nef [12,14], and part of the Gag polyprotein or the nucleocapsid [8-11]. All of these proteins are integral components of the viral preintegration complex (PIC) delivered into cells. These findings seem to suggest that actin may play a role in defining the structure of the virion particle or the PIC. Whether this actin-supported structural integrity is important for viral postentry process such as reverse transcription has not been clearly resolved.

There is some indication that a direct interaction with the actin cytoskeleton following viral entry may be unnecessary or avoidable. Firstly, reverse transcription can be initiated from permeabilized virion particles [88,89], and naturally, HIV particles also contain partially reverse transcribed genomes [90-92]. Secondly, pseudotyping HIV particles with VSV-G, which mediates viral entry through endocytosis, generates highly infectious virus that infects cells with minimal contact with the cortical actin $[15,17,93,94]$. Nevertheless, the DNA molecules found in virion particles are mostly early products of reverse transcription $[90,91]$, and the process of intravirion DNA synthesis is also inefficient; the ratio of genomic RNA to viral DNA is very low, at $10^{3}: 1$ for the early "strong stop" DNA and $10^{5}: 1$ for the late "gag" DNA [89]. These findings are somewhat reminiscent of the reverse transcription reaction using purified reverse transcriptase, in which only the early product of the reverse transcription can be generated [95]. These data suggest that there may be structural constraints in the virion, limiting reverse transcription; alternatively, cellular cofactors such as actin or actin-associated factors may be required. Intriguingly, intravirion reverse transcription can be stimulated using deoxyribonucleoside triphosphates (dNTPs) and detergent to partially disrupt virion structure $[89,96,97]$. These detergent-induced changes include dissolution of the p24 shell in the viral core and disappearance of the core-envelope linkage region [98]. Based on these findings, Zhang et al. suggested that intravirion or intracellular reverse transcription of HIV-1 is unlikely to take place within intact viral cores [98]. Thus, effective viral reverse transcription inside cells may involve an organized process of uncoating or core rearrangement following entry [99-101].

In VSV-G pseudotyped HIV infection, the role of cortical actin in VSV-G-mediated endocytosis is limited to membrane scission of clathrin-coated pits, which does not involve direct contact between the cortical actin and viral particles [102]. The higher infectivity of VSV-G pseudotyped virus could suggest that HIV uncoating or reverse transcription may not need the extensive involvement of the cortical actin in cells. However, Yu et al. demonstrated that, though nuclear migration is more efficient following VSV-G-mediated entry, viral DNA synthesis is decreased [19]. These data suggest that the higher infectivity of the VSV-G pseudotyped particles does not result from higher levels of viral entry, uncoating or reverse transcription, but is largely attributed to the greater ability of VSV-G to deliver the PIC deep into the cytoplasm for nuclear entry. On the other hand, the particles generated by VSV-G pseudotyping may be unnatural or imperfectly formed, especially in the coreenvelope linkage region $[15,98]$. Thus, the uncoating process during VSV-G-mediated endocytic entry may not be as tightly regulated as in the natural HIV particle. Indeed, Brun et al. demonstrated that certain CA mutants that affect core assembly and stability, though defective during wild-type HIV replication, could be rescued by pseudotyping with VSV-G [103]. These results indicate that proper core structure is required for uncoating, reverse transcription and nuclear import when the core is delivered by fusion at the plasma membrane; however, such a requirement is dispensable when the core is delivered through the endocytic pathway. Therefore, the VSV-G-mediated infection may not reflect the genuine uncoating requirements, which may require cortical actin or cortical actin-associated factors. In addition, both Agosto et al. [20] and $\mathrm{Yu}$ et al. [19] demonstrated that, although highly infectious in transformed cells, the VSV-G pseudotyped virus is not capable of infecting resting CD4 $\mathrm{T}$ cells, as viral DNA synthesis is highly diminished [19]. These results, although they do not demonstrate a direct role of cytoskeletal actin in HIV reverse transcription, do suggest that the cortical actin may be involved in the process of uncoating and/or reverse transcription, especially in HIV infection of its natural target cells.

The process of HIV uncoating is poorly studied [104], and there is no specific cellular cofactor identified so far, although there are some suggestions that cellular kinases may be involved [101]. Additionally, it has also been 
suggested that activated $\mathrm{T}$ cells may contain an uncoating factor, whereas resting CD4 T cells do not [105]. Given that the cortical actin is the immediate structure intercepting the virus after membrane fusion, there is a possibility that actin-associated factors or actin activity itself may be a direct driving force for uncoating. The mechanical force generated by actin polymerization and exerted by the lamellipodium on a moving cell has been measured to be in the range of a few nanonewtons $(\mathrm{nN})$ $[106,107]$. It would be interesting to know whether the actin forces triggered during HIV entry are sufficient to destabilize the core structure.

Some of the direct evidence demonstrating a requirement for cytoskeletal actin in HIV reverse transcription came from multiple inhibitor studies as well as recent siRNA knockdown studies of the actin modulators. Iyengar et al. demonstrated that CytoD treatment $(0.2$ to $1 \mu \mathrm{M})$ of PHA-activated peripheral blood mononuclear cells (PBMC) led to inhibition of HIV infection [54]. Nevertheless, the authors concluded that the inhibitory effect of CytoD resulted from specific blockage of viral entry and CD4 and CXCR4 receptor clustering [54]. Bukrinskaya et al. also reported that CytoA, CytoD, and CytoE $(5 \mu \mathrm{M})$ all inhibited HIV infection of a HeLa-CD4 indicator cell [108]. Specifically, CytoD reduced viral early DNA synthesis 4- to 5-fold in MT-4 cells [108]. The study did not distinguish whether the decrease of viral DNA resulted from a loss of entry as proposed by Iyengar [54]. However, the authors argued that the inhibitory effects of cytochalasins were mainly from inhibiting viral DNA synthesis rather than from inhibiting entry, since early viral DNA was abundantly detected in treated cells [108].

Yoder et al. also reported that the actin inhibitor jasplakinolide (Jas) effectively inhibited HIV latent infection of resting CD4 T cells at dosages around $120 \mathrm{nM}$ when $\mathrm{T}$ cell activation was not inhibited by Jas [27]. The inhibition was largely attributed to the inhibition of viral DNA synthesis and nuclear migration, although viral entry was also slightly inhibited by $120 \mathrm{nM}$ Jas [27]. Guo et al. further demonstrated that the Jas inhibition of HIV infection was also dependent on cellular states [29]. For resting CD4 T cells, in which the cytoskeletal actin is relatively static [27], the Jas IC50 dosage for HIV-1 infection was $60 \mathrm{nM}$, whereas for transformed Rev-CEM indicator cells $[109,110]$, the Jas IC $_{50}$ for HIV-1 infection was 250-500 $\mathrm{nM}$ [29]. In addition, increasing actin dynamics through spinoculation increased the $\mathrm{IC}_{50}$ to approximately $1 \mu \mathrm{M}$ for Rev-CEM cells [29]. These results demonstrate that increasing actin dynamics can partially overcome the Jas inhibitory effect on HIV infection. Guo et al. further suggested that the relative sensitivity to Jas could be used as a correlative of actin dynamics in different cell types, and hence, part of their capacity to support HIV infection [29].
A major caveat of using actin inhibitors to study HIV infection is that most of them are associated with general cytotoxicity and have broad effects on cell physiology. Thus, proper controls need to be used to ensure that the inhibition observed is virus specific. Nevertheless, these actin inhibitor studies do appear to be consistent with several siRNA knockdown studies in which the activity of actin modulators such as cofilin and LIMK1 was directly targeted. Yoder et al. demonstrated that slight shRNA-mediated inhibition of cofilin, an actin-depolymerizing factor, in pre-activated blood CD4 $\mathrm{T}$ triggered a drastic increase in the cortical actin density [27]; however, similar knockdown of cofilin in transformed CEM-SS T cells triggered apoptosis [27]. Even in the background of potential cytotoxicity, the increase in the cortical actin in blood CD4 T cells correlated with an increase in HIV DNA synthesis [27]. Consistently, shRNA knockdown of the cofilin kinase LIMK1 decreased the cortical actin density, yet increased CXCR4 receptor trafficking [28]. In the LIMK1 knockdown cells, a decrease in cortical actin was associated with an impairment of viral DNA synthesis following infection with wild type HIV-1, but not with the VSV-G pseudotyped virus [28]. These results demonstrate a direct role of the cortical actin in early viral DNA synthesis. However, these actin inhibitor and siRNA knockdown studies do not provide a mechanistic understanding of why altering actin density or dynamics affect HIV DNA synthesis. Vorster and Guo et al. suggest that the process of actin polymerization may simply act as a driving force for viral uncoating, and thus, decreasing actin dynamics may impair proper uncoating [28]. Alternatively or additionally, the cortical actin may function as an anchorage for the viral reverse transcription complex, and a decrease in the actin cortex density may result in less contact time and suboptimal reverse transcription [28]. Bukrinskaya et al. has also demonstrated that phosphorylated Gag matrix protein (MA) is mainly associated with the HIV preintegration complex (PIC) and with the actin cytoskeleton during early stages of HIV infection, and suggested that actin filaments may be a major site for viral reverse transcription in infected cells [108]. Others have demonstrated that the Gag nucleocapsid protein $(\mathrm{NC})$ rather than MA is the factor that directly interacts with actin [8-11]. Certainly, besides Gag NC, multiple HIV proteins such as the large subunit of the viral reverse transcriptase, the viral integrase, and Nef in the preintegration complex (PIC) are known to directly interact with actin [7,12-14], suggesting possible anchorage of PIC onto the cortical actin for efficient reverse transcription. Among these actin interacting proteins, Nef in particular has been known to enhance viral infectivity by a factor of 4 to 40 [111-113]. This enhancement has been attributed to a positive effect of Nef at 
early steps postentry, such as uncoating or reverse transcription [114-116]. Nef has been known to also interact with the HIV core $[117,118]$ and requires cellular cofactors for enhancement, since Nef-defective virions display normal levels of endogenous reverse transcriptase activity [116]. This positive effect of Nef in infected cells is diminished by actin inhibitors [18] or pseudotyping with VSV-G [15]. These results indicate that the Nefmediated enhancement of viral DNA synthesis is likely related to the cortical actin.

In HIV infection of resting CD4 T cells, viral DNA synthesis is a slow process that takes about 2 days to maximize [27]. After reaching its peak level, viral DNA decreases with time, likely resulting from a concurrent decay process $[27,119]$. Korin and Zack suggested that a lower dNTP level in resting CD4 T cells may limit viral DNA synthesis [120,121]. Yoder and Yu et al. demonstrated that the slower synthesis and decay of viral DNA are also correlated with lower cortical actin dynamics in resting T cells [27]. To increase actin dynamics, the virus utilizes gp120 binding to CXCR4 to trigger a transient course of actin activity through LIMK1 and cofilin $[27,28,32]$. This actin process facilitates viral DNA synthesis and nuclear migration, which may mitigate the viral DNA decay process. As early as $2 \mathrm{~h}$ post infection, a significant fraction of viral DNA is translocated into the nucleus, concurrent with HIV-mediated signaling and actin activity [27]. HIV DNA synthesized in the absence of actin activity may be excluded from nuclear entry and gradually degraded in the cytoplasm of resting $\mathrm{T}$ cells [27]. Consistently, pre-stimulation of resting CD4 T cells with antiCD4/CXCR4 beads reorganized the cortical actin and increased actin dynamics, and this stimulation enhanced viral DNA synthesis and nuclear migration [27]. In addition, Guo et al. demonstrated that spinoculation triggered dynamic actin and cofilin activity, and this process dramatically increased viral DNA synthesis and nuclear migration in resting CD4 $\mathrm{T}$ cells [29]. Furthermore, Campbell et al. demonstrated that stimulation of resting CD4 T cells with CCL2 augmented gp120-induced F-actin polymerization, which enhanced viral DNA synthesis about 5-fold [122]. These results are in agreement with a model in which actin may be involved in viral uncoating and DNA synthesis. In resting T cells, a lessened amount of actin activity may be associated with a slower uncoating rate, which could result in a slower course of viral DNA synthesis and nuclear migration and an increased rate of viral DNA decay.

In summary, based on the above discussion, a possible role of the cortical actin in viral postentry DNA synthesis is described in Figure 1D. Following viral fusion and entry, HIV-mediated actin polymerization may facilitate viral uncoating; the viral preintegration complex may also be directly anchored onto actin filaments through multiple proteins such as the viral nucleocapsid, the large subunit of RT, integrase, and Nef. The anchorage of the preintegration complex onto actin filaments may be important for optimal reverse transcription and subsequent nuclear migration.

\section{Role of actin in HIV intracellular migration}

After, or concomitant with reverse transcription, the viral preintegration complex (PIC) must migrate to the nucleus for integration. The PIC retains many of the viral factors associated with reverse transcription; most notably, the reverse transcriptase, the integrase, the matrix, the nucleocapsid, Vif, Vpr, and Nef [123]. Among these PIC components, the large subunit of the reverse transcriptase, the integrase, the nucleocapsid, and Nef are also known to interact with actin [7-14]. Until recently, there has been very little insight into the possible role of actin in PIC intracellular migration and delivery to the nuclear peripheral zone; however, recent evidence seems to suggest that, once again, actin may play a pivotal role in this essential infective process.

Live cell imaging of GFP-tagged HIV-1 by McDonald et al. [124] revealed microtubule-associated intracellular motility in HeLa and Hos cells, which could be inhibited by microinjection of an anti-dynein motor complex antibody. By $2 \mathrm{~h}$ post-infection, a significant proportion of the labeled particles accumulated in the perinuclear region, often at the microtubule-organizing center (MTOC). Though microtubule or F-actin inhibition alone did not inhibit intracellular migration, a combination of nocodazole and latrunculin $\mathrm{B}$, which disrupt microtubule and actin polymerization respectively, did diminish particle motility [124], suggesting that this process may involve both microtubules and actin. Similarly, Arhel et al., used labeled integrase to track the intracellular movements of VSV-G-pseudotyped HIV-1 in HeLa cells, and suggested that both microtubule- and actin-dependent movements may be involved in HIV migration [125]. Treatment of cells with a dominant-negative dynactin or latrunculin B impaired viral cytosolic movement [125].

Given that a majority of particles in a viral preparation are often not infectious [126] and funneled for degradation after entry $[127,128]$, a cautionary note has been made that these and similar imaging studies [129] may not distinguish replication-competent viruses from the non-infectious particles or particle aggregates, which represent the majority [130]. Yoder et al. used multiple microtubule modulators such as taxol, vinblastine, colchicine, and nocodazole to provide direct biological evidence for the involvement of microtubules in early steps of HIV infection of CD4 T cells [131]. However, the authors observed almost no inhibition of HIV-1 infection, although these drugs disrupted microtubule integrity. These results do not appear to support an essential role of 
microtubules in the initiation of HIV infection of CD4 T cells. In contrast, Yoder et al. observed effective inhibition of HIV latent infection of blood CD4 by the actin inhibitor jasplakinolide at $120 \mathrm{nM}$ [131]. The authors postulated that CD4 $\mathrm{T}$ cells do not have an extensive microtubule network as do HeLa cells, and that the relative thin cytoplasm in $\mathrm{T}$ cells may require only actin-based, shortdistance travel for nuclear localization.

Yoder and $\mathrm{Yu}$ et al. furthered this line of evidence supporting a critical role of the actin cytoskeleton in HIV-1 infection and nuclear migration [27]. The authors suggest that the cortical actin in resting blood CD4 T cells is relatively static in the absence of $\mathrm{T}$ cell activation or chemotactic stimulation. This lack of actin activity may represent a realistic limitation for viral early processes such as entry and intracellular migration. To overcome this limitation, HIV uses the chemokine receptor CXCR4 to trigger the activation of actin modulators such as LIMK1 and cofilin to increase actin dynamics [27,28]. Indeed, the authors demonstrated that inhibition of CXCR4-associated Goi signaling with pertussis toxin inhibited HIV-mediated cofilin activation and actin dynamics, which resulted in a decrease of viral nuclear DNA as early as $2 \mathrm{~h}$ post infection [27]. Similarly, treatment of cells with jasplakinolide diminished both HIV-1 DNA synthesis and nuclear migration [27]. In addition, knockdown of cofilin induced a marked increase in the cortical actin density, which enhanced early HIV DNA synthesis while hindering HIV nuclear migration [27]. These findings were corroborated using supplemental methodologies for increasing actin dynamics. For instance, treatment of cells with anti-CD4 /CXCR4 antibody-conjugated magnetic beads, which mimic viral binding and signaling, greatly stimulates actin dynamics and viral early DNA synthesis and nuclear migration [27]. Induction of actin dynamics through transient treatment with latrunculin A or a cofilin-activating peptide also enhanced HIV latent infection of CD4 T cells [27]. These findings suggest that actin dynamics play a critical role in viral DNA synthesis and nuclear migration in the infection of resting T cells. Furthermore, these findings also demonstrate that HIV actively promotes actin activity through exploiting the chemokine signaling network by choosing the chemokine receptors, CXCR4 and CCR5, as the co-receptors for binding and entry [31].

$\mathrm{Yu}$ et al. supported these findings in a subsequent study regarding the potential role of signaling and actin in the infection of primary CD4 T cells [19]. As per previous studies, VSV-G-pseudotyped HIV-1, which enters cells through endocytosis, exhibits a more efficacious infection in transformed and activated T cells $[15,17]$. However, this effect was not recapitulated in latent infection of resting $\mathrm{T}$ cells: Only the HIV envelope-mediated entry, but not the VSV-G-mediated endocytosis, can lead to viral DNA synthesis and nuclear migration [19]. The viral particles entering through the endocytic pathways were destroyed within 1-2 days. Notably, these findings indicate that the $\mathrm{pH}$-dependent route of entry may not be a viable mechanism in primary resting CD4 T cells [21]; the capacity of HIV gp120 to trigger signaling and to engage the cortical actin seems to be critical for viral postentry stability. Though, this study does not directly lend evidence for the role of actin in viral nuclear migration, within the broader contexts of accumulated findings, this extrapolation is most consistent with that model.

A study by Cameron and Saleh et al. furthered the nascent model regarding the roles of chemokine signaling and actin dynamics in HIV-1 latent infection of blood CD4 T cells [30]. This study focused on the role of chemokines-especially CCL19-in HIV-1 latent infection of resting T cells: Pre-treatment of resting CD4 T cells with the chemokines CCL19, CXCL9, CXCL10, and CCL20 led to a significant increase in integrated viral DNA $[30,132,133]$. More detailed analysis of CCL19 indicated that the mechanism was associated with CCL19-mediated cofilin activation and changes in actin filaments, as the CCL19-mediated enhancement of viral nuclear localization and integration was inhibited by the actin inhibitor jasplakinolide [30]. Cumulatively, these findings suggest that chemokine-mediated actin dynamics play a pivotal role in HIV-1 nuclear migration, and the establishment of latent infection of resting T cells [33].

A recent study by Vorster and Guo et al. further identified the key signaling event involved in HIV-mediated reorganization of actin filaments in resting $\mathrm{T}$ cells [28]. In this study, it was shown that HIV-1 gp120 led to actin dynamics in a manner that correlated with the activation of the Rac-PAK-LIMK-cofilin pathway. Brief treatment of resting $\mathrm{T}$ cells with okadaic acid, a non-specific LIMK activator and phosphatase inhibitor, triggered dramatic LIMK activation and actin polymerization, which led to a significant increase in HIV-1 latent infection. Furthermore, shRNA-mediated knockdown of LIMK1 decreased filamentous actin, increased surface CXCR4 trafficking, and diminished viral DNA synthesis and nuclear migration. These results support the model in which HIVmediated early actin dynamics directly regulates the CXCR4 receptor during viral entry and is involved in viral DNA synthesis and nuclear migration.

The above study also stimulated Guo et al. to postulate that the centrifugal force generated during spinoculation, a technique commonly used to enhance viral infectivity through low speed spinning of cells $(1,000$ 2,000 x g) [134-138], may induce stress-related signaling and actin dynamics [29]. Indeed, spinoculation was found to trigger both cofilin activation and actin dynamics in transformed and resting CD4 T cells [29]. This led to the upregulation of CXCR4 and a great enhancement of HIV-1 DNA synthesis and nuclear migration, which 
can be inhibited by jasplakinolide and shRNA knockdown of LIMK1 [29]. These results highlight the importance of cofilin and a dynamic actin cytoskeleton in the initiation of HIV infection.

Based on these recent studies, the role of the cortical actin in viral postentry migration in CD4 $\mathrm{T}$ cells is summarized in Figure 1D. At the early time following HIV entry, concurrent with the anchorage of the PIC onto actin filaments for reverse transcription, HIV-mediated cofilin activation stimulates actin treadmilling, which may carry the PIC across the cortical actin. Further traveling of the PIC to the perinuclear region may continue to rely on actin filaments or some viral factors such as Nef to trigger localized actin activity.

\section{Relationship between HIV-mediated receptor signaling and actin dynamics}

While it is increasingly clear that cytoskeletal actin is required for viral infection, the relationship between HIV-mediated receptor signaling and actin dynamics is not straightforward. Chemokine receptor signaling normally leads to actin dynamics for driving cell migration. However, multiple previous studies have demonstrated that chemokine coreceptor signaling is not required for viral entry or replication in transformed cell lines [139148]. For example, Farzan et al. created three CCR5 mutants that abolished their signaling ability to mobilize calcium, but detected minimal effects on viral entry or replication [140]. Consistently, CXCR4 mutations that eliminate $\mathrm{G}$ protein-coupled signaling show no inhibition of HIV entry and replication [146,147]; for instance, truncation of the C-terminal tail of CXCR4 or CCR5 effectively blocked calcium flux, but did not affect HIV entry or replication [141,142,144,145]. This is in great contrast to the extensive dependency on signaling molecules observed during cell-cell fusion [59] or HIV-1 infection of resting CD4 T cells $[27,28]$, which appears to require a different signaling environment.

Yoder and $\mathrm{Yu}$ et al. have given an explanation regarding the conflicting observation between viral requirement for actin dynamics and the dispensable role of chemotactic signaling for HIV infection of transformed cells [27]. The authors suggested that in transformed cell lines, the cell cycle takes control of actin dynamics and HIV-mediated signal transduction to the actin cytoskeleton may be diverted or become secondary. This is particularly reflected in HIV infection of transformed versus resting blood CD4 T cells. Yoder and Yu et al. demonstrated that treatment of resting $\mathrm{T}$ cells with HIV particles triggers a transient course of actin activity, indicative of active signal transduction to the actin cytoskeleton; whereas similar treatment of transformed CEM-SS T cells did not trigger any measurable actin activity [27], suggestive of reduced or derailed signals to the actin cytoskeleton. Thus, in cycling cells, while targeting signal transduction from the chemokine coreceptor may not inhibit HIV, directly targeting actin or actin modulators such as cofilin, LIMK, Rac1, WAVE2, and Arp2/3 [27,29,59] would lead to the inhibition of actin dynamics. This may specifically or nonspecifically impact HIV entry or early postentry processes depending on whether the actual activation of signaling molecules occurs in response to HIV binding.

Given the fundamental need for HIV to interact with the actin cytoskeleton, the virus may redundantly use multiple resources to engage the actin network. The virus may use both $\mathrm{CD} 4$ and the chemokine coreceptors to trigger actin dynamics [28]. In addition, HIV may transduce signals leading to actin dynamics from both Goi [27] and Goq [58]. Thus, inhibition of signal transduction from one receptor may not inhibit similar signals from the other. This signaling redundancy may be an evolved functionality of gp120 to ensure that the critical requirements for actin dynamics are met early.

\section{Conclusions}

Recent findings have begun to highlight actin and actin dynamics in HIV replication [149,150]: Actin activity has been shown to be important for viral entry, either for receptor dynamics or stabilization of the fusion complex; actin may additionally be necessary for proper uncoating and efficient reverse transcription; actin dynamics and actin regulators such as LIMK and cofilin are required for efficient nuclear migration in primary target cells such as resting $\mathrm{CD} 4 \mathrm{~T}$ cells. In addition, although beyond the scope of this review, actin may be involved in HIV cell-cell transmission [151-153] and viral assembly and the budding process $[86,87,152,154-157]$. Furthermore, it has also been demonstrated recently that signal transduction from chemokines such as CCL2, CCL19, and CCL21 increases the permissiveness of resting T cells to HIV-1 through induction of actin dynamics [33,122,132,158-160]. These studies not only shed light on the molecular aspects of the HIV life cycle, but also have implications in viral pathogenesis. It is possible that HIV- or viral protein-mediated disruption of actin regulatory network may contribute to viral pathogenesis through disruption of normal chemotactic responses and T cell activity [31,32,161].

Pharmacologically, targeting the actin cytoskeleton may not be practical because of the known cytotoxicity of actin drugs and the need for long-term treatment. However, by interfering with the chemokine receptors or the downstream signaling molecules, a less pervasive disruption of HIV-mediated actin activity is achieved. Approximately $50 \%$ of all marketed therapeutic drugs target $\mathrm{G}$ proteincoupled receptors such as the ones HIV uses [162]. As such, a much-needed future focus should be on the illumination of signal transduction events associated with HIV infection and HIV-mediated actin activity, particularly 
in the primary target cells of HIV. Any so-discovered cellular protein, ideally one of narrow tissue distribution and function, could be a hypothetical target for therapeutic intervention with acceptable adverse effects.

\section{Competing interests}

The authors declare that they have no competing interest.

\section{Acknowledgements}

This work was funded by Public Health Service grant 1R01A1081568 and 1R03Al093157 from NIAID to Y. W.

\section{Authors' contributions}

YW conceived the manuscript and was responsible for organizing the content. YW, MS, JG wrote the manuscript. YW was responsible for creating

Figure 1 and the model. All authors read and approved the final manuscript.

Received: 2 March 2012 Accepted: 3 May 2012

Published: 28 May 2012

\section{References}

1. Pollard TD, Borisy GG: Cellular motility driven by assembly and disassembly of actin filaments. Cell 2003, 112:453-465.

2. Loisel TP, Boujemaa R, Pantaloni D, Carlier MF: Reconstitution of actinbased motility of Listeria and Shigella using pure proteins. Nature 1999, 401:613-616.

3. Cameron LA, Giardini PA, Soo FS, Theriot JA: Secrets of actin-based motility revealed by a bacterial pathogen. Nat Rev Mol Cell Biol 2000, 1:110-119.

4. Frischknecht F, Moreau V, Rottger S, Gonfloni S, Reckmann I, Superti-Furga G, Way M: Actin-based motility of vaccinia virus mimics receptor tyrosine kinase signalling. Nature 1999, 401:926-929.

5. Goley ED, Ohkawa T, Mancuso J, Woodruff JB, D'Alessio JA, Cande WZ, Volkman LE, Welch MD: Dynamic nuclear actin assembly by Arp2/3 complex and a baculovirus WASP-like protein. Science 2006, 314:464-467.

6. Ohkawa T, Volkman LE, Welch MD: Actin-based motility drives baculovirus transit to the nucleus and cell surface. Journal of Cell Biology 2010, 190:187-195.

7. Hottiger M, Gramatikoff K, Georgiev O, Chaponnier C, Schaffner W, Hubscher U: The large subunit of HIV-1 reverse transcriptase interacts with beta-actin. Nucleic Acids Res 1995, 23:736-741.

8. Rey O, Canon J, Krogstad P: HIV-1 Gag protein associates with F-actin present in microfilaments. Virology 1996, 220:530-534.

9. Ibarrondo FJ, Choi R, Geng YZ, Canon J, Rey O, Baldwin GC, Krogstad P: HIV type $1 \mathrm{Gag}$ and nucleocapsid proteins: cytoskeletal localization and effects on cell motility. AIDS Res Hum Retroviruses 2001, 17:1489-1500.

10. Liu B, Dai R, Tian CJ, Dawson L, Gorelick R, Yu XF: Interaction of the human immunodeficiency virus type 1 nucleocapsid with actin. J Virol 1999, 73:2901-2908.

11. Wilk T, Gowen B, Fuller SD: Actin associates with the nucleocapsid domain of the human immunodeficiency virus Gag polyprotein. J Virol 1999, 73:1931-1940.

12. Fackler OT, Kienzle N, Kremmer E, Boese A, Schramm B, Klimkait T, Kucherer C, Mueller-Lantzsch N: Association of human immunodeficiency virus Nef protein with actin is myristoylation dependent and influences its subcellular localization. Eur J Biochem 1997, 247:843-851.

13. Turlure F, Devroe E, Silver PA, Engelman A: Human cell proteins and human immunodeficiency virus DNA integration. Front Biosci 2004, 9:3187-3208.

14. Niederman TM, Hastings WR, Ratner L: Myristoylation-enhanced binding of the HIV-1 Nef protein to T cell skeletal matrix. Virology 1993, 197:420-425.

15. Aiken C: Pseudotyping human immunodeficiency virus type 1 (HIV-1) by the glycoprotein of vesicular stomatitis virus targets HIV-1 entry to an endocytic pathway and suppresses both the requirement for Nef and the sensitivity to cyclosporin A. J Virol 1997, 71:5871-5877.

16. Chazal N, Singer G, Aiken C, Hammarskjold ML, Rekosh D: Human immunodeficiency virus type 1 particles pseudotyped with envelope proteins that fuse at low $\mathrm{pH}$ no longer require Nef for optimal infectivity. J Virol 2001, 75:4014-4018.
17. Luo T, Douglas JL, Livingston RL, Garcia JV: Infectivity enhancement by HIV-1 Nef is dependent on the pathway of virus entry: implications for HIV-based gene transfer systems. Virology 1998, 241:224-233.

18. Campbell EM, Nunez R, Hope TJ: Disruption of the actin cytoskeleton can complement the ability of Nef to enhance human immunodeficiency virus type 1 infectivity. Journal of Virology 2004, 78:5745-5755.

19. Yu D, Wang W, Yoder A, Spear M, WU Y: The HIV envelope but not VSV glycoprotein is capable of mediating HIV latent infection of resting CD4 T cells. PLoS Pathog 2009, 5:e1000633.

20. Agosto LM, Yu JJ, Liszewski MK, Baytop C, Korokhov N, Humeau LM, O'Doherty U: The CXCR4-tropic human immunodeficiency virus envelope promotes more-efficient gene delivery to resting CD4+ T cells than the vesicular stomatitis virus glycoprotein G envelope. J Virol 2009, 83:8153-8162.

21. Miyauchi K, Kim Y, Latinovic O, Morozov V, Melikyan GB: HIV enters cells via endocytosis and dynamin-dependent fusion with endosomes. Cell 2009, 137:433-444.

22. Stein BS, Gowda SD, Lifson JD, Penhallow RC, Bensch KG, Engleman EG: pHindependent HIV entry into CD4-positive T cells via virus envelope fusion to the plasma membrane. Cell 1987, 49:659-668.

23. Maddon PJ, McDougal JS, Clapham PR, Dalgleish AG, Jamal S, Weiss RA, Axel R: HIV infection does not require endocytosis of its receptor, CD4. Cell 1988, 54:865-874.

24. McClure MO, Marsh M, Weiss RA: Human immunodeficiency virus infection of CD4-bearing cells occurs by a pH-independent mechanism. Embo J 1988, 7:513-518.

25. Brandt SM, Mariani R, Holland AU, Hope TJ, Landau NR: Association of chemokine-mediated block to HIV entry with coreceptor internalization. J Biol Chem 2002, 277:17291-17299.

26. Pelchen-Matthews A, Clapham P, Marsh M: Role of CD4 endocytosis in human immunodeficiency virus infection. J Virol 1995, 69:8164-8168.

27. Yoder A, Yu D, Dong L, lyer SR, Xu X, Kelly J, Liu J, Wang W, Vorster PJ, Agulto $L$, et al: HIV envelope-CXCR4 signaling activates cofilin to overcome cortical actin restriction in resting CD4 T cells. Cell 2008, 134:782-792.

28. Vorster PJ, Guo J, Yoder A, Wang W, Zheng Y, Xu X, Yu D, Spear M, Wu Y: LIM kinase 1 modulates cortical actin and CXCR4 cycling and is activated by HIV-1 to initiate viral infection. J Biol Chem 2011, 286:12554-12564.

29. Guo J, Wang $W, Y u$ D, Wu Y: Spinoculation triggers dynamic actin and cofilin activity facilitating HIV-1 infection of transformed and resting CD4 T cells. J Virol 2011, 85:9824-9833.

30. Cameron PU, Saleh S, Sallmann G, Solomon A, Wightman F, Evans VA Boucher G, Haddad EK, Sekaly RP, Harman AN, et al: Establishment of HIV-1 latency in resting CD4+ T cells depends on chemokine-induced changes in the actin cytoskeleton. Proc Natl Acad Sci U S A 2010, 107:16934-16939.

31. Wu Y, Yoder A: Chemokine coreceptor signaling in HIV-1 infection and pathogenesis. PLoS Pathog 2009, 5:e1000520.

32. Wu Y: The co-receptor signaling model of HIV-1 pathogenesis in peripheral CD4 T cells. Retrovirology 2009, 6:41.

33. WU Y: Chemokine control of HIV-1 infection: beyond a binding competition. Retrovirology 2010, 7:86.

34. Bukrinsky M: How to engage Cofilin. Retrovirology 2008, 5:85.

35. Liu Y, Belkina NV, Shaw S: HIV infection of T cells: actin-in and actin-out. Sci Signal 2009, 2:pe23.

36. Klatzmann D, Barre-Sinoussi F, Nugeyre MT, Danquet C, Vilmer E, Griscelli C, Brun-Veziret F, Rouzioux C, Gluckman JC, Chermann JC, et al: Selective tropism of lymphadenopathy associated virus (LAV) for helper-inducer $T$ lymphocytes. Science 1984, 225:59-63.

37. Klatzmann D, Champagne E, Chamaret S, Gruest J, Guetard D, Hercend T, Gluckman JC, Montagnier L: T-lymphocyte T4 molecule behaves as the receptor for human retrovirus LAV. Nature 1984, 312:767-768.

38. Dalgleish AG, Beverley PC, Clapham PR, Crawford DH, Greaves MF, Weiss RA: The CD4 (T4) antigen is an essential component of the receptor for the AIDS retrovirus. Nature 1984, 312:763-767.

39. McDougal JS, Mawle A, Cort SP, Nicholson JK, Cross GD, Scheppler-Campbell JA, Hicks D, Sligh J: Cellular tropism of the human retrovirus HTLV-III/LAV. I. Role of T cell activation and expression of the T4 antigen. J Immunol 1985, 135:3151-3162.

40. McDougal JS, Kennedy MS, Sligh JM, Cort SP, Mawle A, Nicholson JK: Binding of HTLV-III/LAV to T4+ T cells by a complex of the $110 \mathrm{~K}$ viral protein and the T4 molecule. Science 1986, 231:382-385. 
41. Maddon PJ, Dalgleish AG, McDougal JS, Clapham PR, Weiss RA, Axel R: The T4 gene encodes the AIDS virus receptor and is expressed in the immune system and the brain. Cell 1986, 47:333-348.

42. Feng $Y$, Broder CC, Kennedy PE, Berger EA: HIV-1 entry cofactor: functional CDNA cloning of a seven-transmembrane, $G$ protein-coupled receptor. Science 1996, 272:872-877.

43. Cocchi F, DeVico AL, Garzino-Demo A, Arya SK, Gallo RC, Lusso P: Identification of RANTES, MIP-1 alpha, and MIP-1 beta as the major HIV-suppressive factors produced by CD8+ T cells. Science 1995 270:1811-1815.

44. Alkhatib G, Combadiere C, Broder CC, Feng Y, Kennedy PE, Murphy PM, Berger EA: CC CKR5: a RANTES, MIP-1alpha, MIP-1beta receptor as a fusion cofactor for macrophage-tropic HIV-1. Science 1996, 272:1955-1958.

45. Choe H, Farzan M, Sun Y, Sullivan N, Rollins B, Ponath PD, Wu L, Mackay CR, LaRosa G, Newman W, et al: The beta-chemokine receptors CCR3 and CCR5 facilitate infection by primary HIV-1 isolates. Cell 1996, 85:1135-1148.

46. Deng H, Liu R, Ellmeier W, Choe S, Unutmaz D, Burkhart M, Di Marzio P, Marmon S, Sutton RE, Hill CM, et al: Identification of a major co-receptor for primary isolates of HIV-1. Nature 1996, 381:661-666.

47. Doranz BJ, Rucker J, Yi Y, Smyth RJ, Samson M, Peiper SC, Parmentier M, Collman RG, Doms RW: A dual-tropic primary HIV-1 isolate that uses fusin and the beta-chemokine receptors CKR-5, CKR-3, and CKR-2b as fusion cofactors. Cell 1996, 85:1149-1158.

48. Dragic T, Litwin V, Allaway GP, Martin SR, Huang Y, Nagashima KA, Cayanan C, Maddon PJ, Koup RA, Moore JP, Paxton WA: HIV-1 entry into CD4+ cells is mediated by the chemokine receptor CC-CKR-5. Nature 1996, 381:667-673.

49. Lapham CK, Ouyang J, Chandrasekhar B, Nguyen NY, Dimitrov DS, Golding $\mathrm{H}$ : Evidence for cell-surface association between fusin and the CD4gp120 complex in human cell lines. Science 1996, 274:602-605.

50. Wu L, Gerard NP, Wyatt R, Choe H, Parolin C, Ruffing N, Borsetti A, Cardoso $A A$, Desjardin E, Newman W, et al: CD4-induced interaction of primary HIV-1 gp120 glycoproteins with the chemokine receptor CCR-5. Nature 1996, 384:179-183

51. Trkola A, Dragic T, Arthos J, Binley JM, Olson WC, Allaway GP, Cheng-Maye C, Robinson J, Maddon PJ, Moore JP: CD4-dependent, antibody-sensitive interactions between HIV-1 and its co-receptor CCR-5. Nature 1996, 384:184-187.

52. Hill CM, Deng H, Unutmaz D, Kewalramani VN, Bastiani L, Gorny MK Zolla-Pazner S, Littman DR: Envelope glycoproteins from human immunodeficiency virus types 1 and 2 and simian immunodeficiency virus can use human CCR5 as a coreceptor for viral entry and make direct CD4-dependent interactions with this chemokine receptor. J Virol 1997, 71:6296-6304

53. Ugolini S, Moulard M, Mondor I, Barois N, Demandolx D, Hoxie J, Brelot A, Alizon M, Davoust J, Sattentau QJ: HIV-1 gp120 induces an association between CD4 and the chemokine receptor CXCR4. J Immunol 1997, 159:3000-3008.

54. lyengar S, Hildreth JE, Schwartz DH: Actin-dependent receptor colocalization required for human immunodeficiency virus entry into host cells. J Virol 1998, 72:5251-5255.

55. Jimenez-Baranda S, Gomez-Mouton C, Rojas A, Martinez-Prats L, Mira E, Ana Lacalle $R$, Valencia A, Dimitrov DS, Viola A, Delgado $R$, et al: Filamin-A regulates actin-dependent clustering of HIV receptors. Nat Cell Biol 2007, 9:838-846.

56. Barrero-Villar M, Cabrero JR, Gordon-Alonso M, Barroso-Gonzalez J, Alvarez-Losada S, Munoz-Fernandez MA, Sanchez-Madrid F, Valenzuela-Fernandez A: Moesin is required for HIV-1-induced CD4-CXCR4 interaction, F-actin redistribution, membrane fusion and viral infection in lymphocytes. J Cell Sci 2009, 122:103-113.

57. Pontow SE, Heyden NV, Wei S, Ratner L: Actin cytoskeletal reorganizations and coreceptor-mediated activation of rac during human immunodeficiency virus-induced cell fusion. Journal of Virology 2004 78:7138-7147.

58. Harmon B, Ratner L: Induction of the Galpha(q) signaling cascade by the human immunodeficiency virus envelope is required for virus entry. Virol 2008, 82:9191-9205.

59. Harmon B, Campbell N, Ratner L: Role of Abl kinase and the Wave2 signaling complex in HIV-1 entry at a post-hemifusion step. PLOS Pathog 2010, 6:e1000956.

60. Lapham CK, Zaitseva MB, Lee S, Romanstseva T, Golding H: Fusion of monocytes and macrophages with HIV-1 correlates with biochemical properties of CXCR4 and CCR5. Nat Med 1999, 5:303-308.
61. Xiao X, Wu L, Stantchev TS, Feng YR, Ugolini S, Chen H, Shen Z, Riley JL, Broder CC, Sattentau QJ, Dimitrov DS: Constitutive cell surface association between CD4 and CCR5. Proc Natl Acad Sci U S A 1999, 96:7496-7501.

62. Singer II, Scott S, Kawka DW, Chin J, Daugherty BL, DeMartino JA, DiSalvo J, Gould SL, Lineberger JE, Malkowitz L, et al: CCR5, CXCR4, and CD4 are clustered and closely apposed on microvilli of human macrophages and T cells. J Virol 2001, 75:3779-3790

63. Baker AM, Sauliere A, Gaibelet G, Lagane B, Mazeres S, Fourage M, Bachelerie F, Salome L, Lopez A, Dumas F: CD4 interacts constitutively with multiple CCR5 at the plasma membrane of living cells. A fluorescence recovery after photobleaching at variable radii approach. $J$ Biol Chem 2007, 282:35163-35168.

64. Toth PT, Ren D, Miller RJ: Regulation of CXCR4 receptor dimerization by the chemokine SDF-1alpha and the HIV-1 coat protein gp120: a fluorescence resonance energy transfer (FRET) study. J Pharmacol Exp Ther 2004, 310:8-17.

65. Seror C, Melki MT, Subra F, Raza SQ, Bras M, Saidi H, Nardacci R, Voisin L, Paoletti A, Law F, et al: Extracellular ATP acts on P2Y2 purinergic receptors to facilitate HIV-1 infection. J Exp Med 2011, 208:1823-1834.

66. Platt EJ, Wehrly K, Kuhmann SE, Chesebro B, Kabat D: Effects of CCR5 and CD4 cell surface concentrations on infections by macrophagetropic isolates of human immunodeficiency virus type 1. J Virol 1998, 72:2855-2864.

67. Layne SP, Merges MJ, Dembo M, Spouge JL, Nara PL: HIV requires multiple gp120 molecules for CD4-mediated infection. Nature 1990, 346:277-279.

68. Kuhmann SE, Platt EJ, Kozak SL, Kabat D: Cooperation of multiple CCR5 coreceptors is required for infections by human immunodeficiency virus type 1. J Virol 2000, 74:7005-7015.

69. Sougrat R, Bartesaghi A, Lifson JD, Bennett AE, Bess JW, Zabransky DJ, Subramaniam S: Electron tomography of the contact between T cells and SIV/HIV-1: implications for viral entry. PLoS Pathog 2007, 3:e63.

70. Del Real G, Jimenez-Baranda S, Lacalle RA, Mira E, Lucas P, Gomez-Mouton C, Carrera AC, Martinez AC, Manes S: Blocking of HIV-1 infection by targeting CD4 to nonraft membrane domains. J Exp Med 2002, 196:293-301.

71. Manes S, del Real G, Lacalle RA, Lucas P, Gomez-Mouton C, Sanchez-Palomino S, Delgado R, Alcami J, Mira E, Martinez AC: Membrane raft microdomains mediate lateral assemblies required for HIV-1 infection. EMBO Rep 2000, 1:190-196.

72. Popik W, Alce TM, Au WC: Human immunodeficiency virus type 1 uses lipid raft-colocalized CD4 and chemokine receptors for productive entry into CD4(+) T cells. J Virol 2002, 76:4709-4722.

73. Kamiyama H, Yoshii H, Tanaka Y, Sato H, Yamamoto N, Kubo Y: Raft localization of CXCR4 is primarily required for X4-tropic human immunodeficiency virus type 1 infection. Virology 2009, 386:23-31.

74. Nguyen DH, Giri B, Collins G, Taub DD: Dynamic reorganization of chemokine receptors, cholesterol, lipid rafts, and adhesion molecules to sites of CD4 engagement. Exp Cell Res 2005, 304:559-569.

75. Popik W, Alce TM: CD4 receptor localized to non-raft membrane microdomains supports HIV-1 entry. Identification of a novel raft localization marker in CD4. J Biol Chem 2004, 279:704-712.

76. Percherancier $Y$, Lagane B, Planchenault T, Staropoli I, Altmeyer R, Virelizier JL, Arenzana-Seisdedos F, Hoessli DC, Bachelerie F: HIV-1 entry into T-cells is not dependent on CD4 and CCR5 localization to sphingolipid-enriched, detergent-resistant, raft membrane domains. J Biol Chem 2003, 278:3153-3161.

77. Balabanian K, Harriague J, Decrion C, Lagane B, Shorte S, Baleux F, Virelizier $J$, Arenzana-Seisdedos F, Chakrabarti LA: CXCR4-tropic HIV-1 envelope glycoprotein functions as a viral chemokine in unstimulated primary CD4+ T lymphocytes. J Immunol 2004, 173:7150-7160

78. Chang MI, Panorchan P, Dobrowsky TM, Tseng Y, Wirtz D: Single-molecule analysis of human immunodeficiency virus type $1 \mathrm{gp} 120$-receptor interactions in living cells. J Virol 2005, 79:14748-14755.

79. Gallo SA, Reeves JD, Garg H, Foley B, Doms RW, Blumenthal R: Kinetic studies of HIV-1 and HIV-2 envelope glycoprotein-mediated fusion. Retrovirology 2006, 3:90.

80. Gallo SA, Puri A, Blumenthal R: HIV-1 gp41 six-helix bundle formation occurs rapidly after the engagement of gp 120 by CXCR4 in the HIV- 1 Env-mediated fusion process. Biochemistry 2001, 40:12231-12236.

81. Readinger JA, Schiralli GM, Jiang JK, Thomas CJ, August A, Henderson AJ, Schwartzberg PL: Selective targeting of ITK blocks multiple steps of HIV replication. Proc Natl Acad Sci U S A 2008, 105:6684-6689. 
82. Weissman D, Rabin RL, Arthos J, Rubbert A, Dybul M, Swofford R, Venkatesan S, Farber JM, Fauci AS: Macrophage-tropic HIV and SIV envelope proteins induce a signal through the CCR5 chemokine receptor. Nature 1997, 389:981-985.

83. Komano J, Miyauchi K, Matsuda Z, Yamamoto N: Inhibiting the Arp2/3 complex limits infection of both intracellular mature vaccinia virus and primate lentiviruses. Mol Biol Cell 2004, 15:5197-5207.

84. Naghavi MH, Valente S, Hatziioannou T, de Los Santos K, Wen Y, Mott C, Gundersen GG, Goff SP: Moesin regulates stable microtubule formation and limits retroviral infection in cultured cells. Embo J 2007, 26:41-52.

85. Arthur LO, Bess JW Jr, Sowder RC, Benveniste RE, Mann DL, Chermann JC, Henderson LE: Cellular proteins bound to immunodeficiency viruses: implications for pathogenesis and vaccines. Science 1992, 258:1935-1938.

86. Ott DE, Coren LV, Johnson DG, Kane BP, Sowder RC, Kim YD, Fisher RJ, Zhou $X Z$, Lu KP, Henderson LE: Actin-binding cellular proteins inside human immunodeficiency virus type 1. Virology 2000, 266:42-51.

87. Ott DE, Coren LV, Kane BP, Busch LK, Johnson DG, Sowder RC, Chertova EN, Arthur LO, Henderson LE: Cytoskeletal proteins inside human immunodeficiency virus type 1 virions. J Virol 1996, 70:7734-7743.

88. Junghans RP, Duesberg PH, Knight CA: In vitro synthesis of full-length DNA transcripts of Rous sarcoma virus RNA by viral DNA polymerase. Proc Natl Acad Sci U S A 1975, 72:4895-4899.

89. Zhang H, Zhang Y, Spicer TP, Abbott LZ, Abbott M, Poiesz BJ: Reverse transcription takes place within extracellular HIV-1 virions: potential biological significance. AIDS Res Hum Retroviruses 1993, 9:1287-1296.

90. Lori F, di Marzo Veronese F, de Vico AL, Lusso P, Reitz MS Jr, Gallo RC: Viral DNA carried by human immunodeficiency virus type 1 virions. J Virol 1992, 66:5067-5074.

91. Trono D: Partial reverse transcripts in virions from human immunodeficiency and murine leukemia viruses. J Virol 1992, 66:4893-4900

92. Warrilow D, Stenzel D, Harrich D: Isolated HIV-1 core is active for reverse transcription. Retrovirology 2007, 4:77

93. Naldini L, Blomer U, Gallay P, Ory D, Mulligan R, Gage FH, Verma IM, Trono $D$ : In vivo gene delivery and stable transduction of nondividing cells by a lentiviral vector. Science 1996, 272:263-267.

94. Reiser J, Harmison G, Kluepfel-Stahl S, Brady RO, Karlsson S, Schubert M: Transduction of nondividing cells using pseudotyped defective high-titer HIV type 1 particles. Proc Natl Acad Sci U S A 1996, 93:15266-15271.

95. Varmus HE, Padgett T, Heasley S, Simon G, Bishop JM: Cellular functions are required for the synthesis and integration of avian sarcoma virusspecific DNA. Cell 1977, 11:307-319.

96. Zhang H, Bagasra O, Niikura M, Poiesz BJ, Pomerantz RJ: Intravirion reverse transcripts in the peripheral blood plasma on human immunodeficiency virus type 1-infected individuals. J Virol 1994, 68:7591-7597.

97. Zhang H, Zhang Y, Spicer T, Henrard D, Poiesz BJ: Nascent human immunodeficiency virus type 1 reverse transcription occurs within an enveloped particle. J Virol 1995, 69:3675-3682

98. Zhang H, Dornadula G, Orenstein J, Pomerantz RJ: Morphologic changes in human immunodeficiency virus type 1 virions secondary to intravirion reverse transcription: evidence indicating that reverse transcription may not take place within the intact viral core. J Hum Virol 2000, 3:165-172.

99. Forshey BM, von Schwedler U, Sundquist WI, Aiken C: Formation of a human immunodeficiency virus type 1 core of optimal stability is crucial for viral replication. J Virol 2002, 76:5667-5677.

100. Dismuke DJ, Aiken C: Evidence for a functional link between uncoating of the human immunodeficiency virus type 1 core and nuclear import of the viral preintegration complex. J Virol 2006, 80:3712-3720.

101. Warrilow D, Harrich D: HIV-1 replication from after cell entry to the nuclear periphery. Curr HIV Res 2007, 5:293-299.

102. Merrifield CJ, Perrais D, Zenisek D: Coupling between clathrin-coated-pit invagination, cortactin recruitment, and membrane scission observed in live cells. Cell 2005, 121:593-606.

103. Brun S, Solignat M, Gay B, Bernard E, Chaloin L, Fenard D, Devaux C, Chazal $\mathrm{N}$, Briant L: VSV-G pseudotyping rescues HIV-1 CA mutations that impair core assembly or stability. Retrovirology 2008, 5:57.

104. Arhel N: Revisiting HIV-1 uncoating. Retrovirology 2011, 7:96.

105. Auewarakul P, Wacharapornin P, Srichatrapimuk S, Chutipongtanate S, Puthavathana P: Uncoating of HIV-1 requires cellular activation. Virology 2005, 337:93-101.
106. Marcy Y, Prost J, Carlier MF, Sykes C: Forces generated during actin-based propulsion: a direct measurement by micromanipulation. Proc Natl Acad Sci U S A 2004, 101:5992-5997.

107. Abraham VC, Krishnamurthi V, Taylor DL, Lanni F: The actin-based nanomachine at the leading edge of migrating cells. Biophys J 1999 77:1721-1732.

108. Bukrinskaya A, Brichacek B, Mann A, Stevenson M: Establishment of a functional human immunodeficiency virus type 1 (HIV-1) reverse transcription complex involves the cytoskeleton. J Exp Med 1998, 188:2113-2125.

109. Wu Y, Beddall MH, Marsh JW: Rev-dependent lentiviral expression vector. Retrovirology 2007, 4:12

110. Wu Y, Beddall MH, Marsh JW: Rev-dependent indicator T cell line. Current HIV Research 2007, 5:395-403.

111. Kestler HWd, Ringler DJ, Mori K, Panicali DL, Sehgal PK, Daniel MD, Desrosiers RC: Importance of the nef gene for maintenance of high virus loads and for development of AIDS. Cell 1991, 65:651-662.

112. Chowers MY, Spina CA, Kwoh TJ, Fitch NJ, Richman DD, Guatelli JC: Optimal infectivity in vitro of human immunodeficiency virus type 1 requires an intact nef gene. J Virol 1994, 68:2906-2914.

113. Miller MD, Warmerdam MT, Gaston I, Greene WC, Feinberg MB: The human immunodeficiency virus-1 nef gene product: a positive factor for viral infection and replication in primary lymphocytes and macrophages. $J$ Exp Med 1994, 179:101-113.

114. Aiken C, Trono D: Nef stimulates human immunodeficiency virus type 1 proviral DNA synthesis. J Virol 1995, 69:5048-5056.

115. Chowers MY, Pandori MW, Spina CA, Richman DD, Guatelli JC: The growth advantage conferred by HIV-1 nef is determined at the level of viral DNA formation and is independent of CD4 downregulation. Virology 1995, 212:451-457.

116. Schwartz O, Marechal V, Danos O, Heard JM: Human immunodeficiency virus type 1 Nef increases the efficiency of reverse transcription in the infected cell. J Virol 1995, 69:4053-4059.

117. Kotov A, Zhou J, Flicker P, Aiken C: Association of Nef with the human immunodeficiency virus type 1 core. J Virol 1999, 73:8824-8830.

118. Forshey BM, Aiken C: Disassembly of human immunodeficiency virus type 1 cores in vitro reveals association of Nef with the subviral ribonucleoprotein complex. J Virol 2003, 77:4409-4414.

119. Zhou $Y$, Zhang H, Siliciano JD, Siliciano RF: Kinetics of human immunodeficiency virus type 1 decay following entry into resting CD4+ T cells. J Virol 2005, 79:2199-2210.

120. Zack JA, Arrigo SJ, Weitsman SR, Go AS, Haislip A, Chen IS: HIV-1 entry into quiescent primary lymphocytes: molecular analysis reveals a labile, latent viral structure. Cell 1990, 61:213-222.

121. Korin YD, Zack JA: Nonproductive human immunodeficiency virus type 1 infection in nucleoside-treated G0 lymphocytes. J Virol 1999, 73:6526-6532.

122. Campbell GR, Spector SA: CCL2 increases X4-tropic HIV-1 entry into resting CD4+ T cells. J Biol Chem 2008, 283:30745-30753.

123. Miller MD, Farnet CM, Bushman FD: Human immunodeficiency virus type 1 preintegration complexes: studies of organization and composition. $J$ Virol 1997, 71:5382-5390

124. McDonald D, Vodicka MA, Lucero G, Svitkina TM, Borisy GG, Emerman M, Hope TJ: Visualization of the intracellular behavior of HIV in living cells. J Cell Biol 2002, 159:441-452.

125. Arhel N, Genovesio A, Kim KA, Miko S, Perret E, Olivo-Marin JC, Shorte S, Charneau P: Quantitative four-dimensional tracking of cytoplasmic and nuclear HIV-1 complexes. Nat Methods 2006, 3:817-824.

126. Kimpton J, Emerman M: Detection of replication-competent and pseudotyped human immunodeficiency virus with a sensitive cell line on the basis of activation of an integrated beta-galactosidase gene. $J$ Virol 1992, 66:2232-2239.

127. Fredericksen BL, Wei BL, Yao J, Luo T, Garcia JV: Inhibition of endosomal/ lysosomal degradation increases the infectivity of human immunodeficiency virus. J Virol 2002, 76:11440-11446.

128. Wei BL, Denton PW, O'Neill E, Luo T, Foster JL, Garcia JV: Inhibition of lysosome and proteasome function enhances human immunodeficiency virus type 1 infection. J Virol 2005, 79:5705-5712.

129. Zamborlini A, Lehmann-Che J, Clave E, Giron ML, Tobaly-Tapiero J, Roingeard $P$, Emiliani S, Toubert A, de The H, Saib A: Centrosomal pre-integration latency of HIV-1 in quiescent cells. Retrovirology 2007, 4:63.

130. Suzuki Y, Craigie R: The road to chromatin - nuclear entry of retroviruses. Nat Rev Microbiol 2007, 5:187-196. 
131. Yoder A, Guo J, Yu D, Cui Z, Zhang XE, Wu Y: Effects of Microtubule Modulators on HIV-1 Infection of Transformed and Resting CD4 T Cells. J Virol 2011, 85:3020-3024

132. Saleh S, Solomon A, Wightman F, Xhilaga M, Cameron PU, Lewin SR: CCR7 ligands CCL19 and CCL21 increase permissiveness of resting memory CD4+ T cells to HIV-1 infection: a novel model of HIV-1 latency. Blood 2007, 110:4161-4164.

133. Cameron PU, Saleh SM, Sallman G, Solomon A, Wightman F, Mark J, Hones K, Anderson J, Jaworowski A, Lewin SR: Latent HIV infection can be established in resting CD4+ T-cells in vitro following incubation with multiple diverse chemokines which facilitate nuclear import of the pre-integration complex. 4th international workship in HIV persistence during therapy 2009, 2009:8-11.

134. Gey GO, Bang FB, Gey MK: Responses of a variety of normal and malignant cells to continuous cultivation, and some practical applications of these responses to problems in the biology of disease. Ann N Y Acad Sci 1954, 58:976-999.

135. Bunnell BA, Muul LM, Donahue RE, Blaese RM, Morgan RA: High-efficiency retroviral-mediated gene transfer into human and nonhuman primate peripheral blood lymphocytes. Proc Natl Acad Sci U S A 1995, 92:7739-7743.

136. Forestell SP, Dando JS, Bohnlein E, Rigg RJ: Improved detection of replication-competent retrovirus. J Virol Methods 1996, 60:171-178.

137. Ho WZ, Cherukuri R, Ge SD, Cutilli JR, Song L, Whitko S, Douglas SD: Centrifugal enhancement of human immunodeficiency virus type 1 infection and human cytomegalovirus gene expression in human primary monocyte/macrophages in vitro. J Leukoc Biol 1993, 53:208-212.

138. O'Doherty U, Swiggard WJ, Malim MH: Human immunodeficiency virus type 1 spinoculation enhances infection through virus binding. J Virol 2000, 74:10074-10080

139. Cocchi F, DeVico AL, Garzino-Demo A, Cara A, Gallo RC, Lusso P: The V3 domain of the HIV-1 gp120 envelope glycoprotein is critical for chemokine-mediated blockade of infection. Nat Med 1996, 2:1244-1247.

140. Farzan M, Choe H, Martin KA, Sun Y, Sidelko M, Mackay CR, Gerard NP, Sodroski J, Gerard C: HIV-1 entry and macrophage inflammatory protein-1 beta-mediated signaling are independent functions of the chemokine receptor CCR5. Journal of Biological Chemistry 1997 272:6854-6857.

141. Alkhatib G, Locati M, Kennedy PE, Murphy PM, Berger EA: HIV-1 coreceptor activity of CCR5 and its inhibition by chemokines: independence from $G$ protein signaling and importance of coreceptor downmodulation. Virology 1997, 234:340-348.

142. Gosling J, Monteclaro FS, Atchison RE, Arai H, Tsou CL, Goldsmith MA, Charo IF: Molecular uncoupling of C-C chemokine receptor 5-induced chemotaxis and signal transduction from HIV-1 coreceptor activity. Proc Natl Acad Sci U S A 1997, 94:5061-5066.

143. Aramori I, Ferguson SS, Bieniasz PD, Zhang J, Cullen B, Cullen MG: Molecular mechanism of desensitization of the chemokine receptor CCR-5: receptor signaling and internalization are dissociable from its role as an HIV-1 co-receptor. Embo J 1997, 16:4606-4616.

144. Amara A, Gall SL, Schwartz O, Salamero J, Montes M, Loetscher P, Baggiolini M, Virelizier JL, Arenzana-Seisdedos F: HIV coreceptor downregulation as antiviral principle: SDF-1alpha-dependent internalization of the chemokine receptor CXCR4 contributes to inhibition of HIV replication. J Exp Med 1997, 186:139-146.

145. Lu Z, Berson JF, Chen Y, Turner JD, Zhang T, Sharron M, Jenks MH, Wang Z, Kim J, Rucker J, et al: Evolution of HIV-1 coreceptor usage through interactions with distinct CCR5 and CXCR4 domains. Proc Natl Acad Sci U S A 1997, 94:6426-6431.

146. Doranz BJ, Orsini MJ, Turner JD, Hoffman TL, Berson JF, Hoxie JA, Peiper SC, Brass LF, Doms RW: Identification of CXCR4 domains that support coreceptor and chemokine receptor functions. J Virol 1999, 73:2752-2761.

147. Brelot A, Heveker N, Montes M, Alizon M: Identification of residues of CXCR4 critical for human immunodeficiency virus coreceptor and chemokine receptor activities. J Biol Chem 2000, 275:23736-23744.

148. Amara A, Vidy A, Boulla G, Mollier K, Garcia-Perez J, Alcami J, Blanpain C, Parmentier M, Virelizier JL, Charneau P, Arenzana-Seisdedos F: G proteindependent CCR5 signaling is not required for efficient infection of primary T lymphocytes and macrophages by R5 human immunodeficiency virus type 1 isolates. Journal of Virology 2003, 77:2550-2558.

149. Stolp B, Fackler OT: How HIV takes advantage of the cytoskeleton in entry and replication. Viruses 2011, 3:293-311.
150. Taylor MP, Koyuncu OO, Enquist LW: Subversion of the actin cytoskeleton during viral infection. Nat Rev Microbiol 2011, 9:427-439.

151. Lehmann M, Nikolic DS, Piguet V: How HIV-1 takes advantage of the cytoskeleton during replication and cell-to-cell transmission. Viruses 2011, 3:1757-1776.

152. Jolly C, Kashefi K, Hollinshead M, Sattentau QJ: HIV-1 cell to cell transfer across an Env-induced, actin-dependent synapse. J Exp Med 2004, 199:283-293.

153. Vasiliver-Shamis G, Cho MW, Hioe CE, Dustin ML: Human immunodeficiency virus type 1 envelope gp120-induced partial T-cell receptor signaling creates an F-actin-depleted zone in the virological synapse. J Virol 2009, 83:11341-11355.

154. Jolly C, Mitar I, Sattentau QJ: Requirement for an intact T-cell actin and tubulin cytoskeleton for efficient assembly and spread of human immunodeficiency virus type 1. J Virol 2007, 81:5547-5560.

155. Gladnikoff M, Shimoni E, Gov NS, Rousso I: Retroviral assembly and budding occur through an actin-driven mechanism. Biophys J 2009, 97:2419-2428

156. Cooper J, Liu L, Woodruff EA, Taylor HE, Goodwin JS, D'Aquila RT, Spearman $P$, Hildreth JE, Dong $X$ : Filamin A protein interacts with human immunodeficiency virus type $1 \mathrm{Gag}$ protein and contributes to productive particle assembly. J Biol Chem 2011, 286:28498-28510.

157. Graziano F, Elia C, Laudanna C, Poli G, Alfano M: Urokinase plasminogen activator inhibits HIV virion release from macrophage-differentiated chronically infected cells via activation of RhoA and PKCepsilon. PLoS One 2011, 6:e23674.

158. Ansari AW, Bhatnagar N, Dittrich-Breiholz O, Kracht M, Schmidt RE, Heiken H: Host chemokine (C-C motif) ligand-2 (CCL2) is differentially regulated in HIV type 1 (HIV-1)-infected individuals. Int Immunol 2006, 18:1443-1451.

159. Damas JK, Landro L, Fevang B, Heggelund L, Froland SS, Aukrust P: Enhanced levels of the CCR7 ligands CCL19 and CCL21 in HIV infection: correlation with viral load, disease progression and response to highly active antiretroviral therapy. Aids 2009, 23:135-138.

160. Damas JK, Landro L, Fevang B, Heggelund L, Tjonnfjord GE, Floisand $Y$, Halvorsen B, Froland SS, Aukrust P: Homeostatic chemokines CCL19 and CCL21 promote inflammation in human immunodeficiency virusinfected patients with ongoing viral replication. Clin Exp Immunol 2009, 157:400-407.

161. Wu Y, Yoder A, Yu D, Wang W, Liu J, Barrett T, Wheeler D, Schlauch K: Cofilin activation in peripheral CD4 T cells of HIV-1 infected patients: a pilot study. Retrovirology 2008, 5:95.

162. Howard AD, McAllister G, Feighner SD, Liu Q, Nargund RP, Van der Ploeg $\mathrm{LH}$, Patchett AA: Orphan G-protein-coupled receptors and natural ligand discovery. Trends Pharmaco/ Sci 2001, 22:132-140.

doi:10.1186/1742-4690-9-45

Cite this article as: Spear et al:: The trinity of the cortical actin in the initiation of HIV-1 infection. Retrovirology 2012 9:45.

\section{Submit your next manuscript to BioMed Central and take full advantage of:}

- Convenient online submission

- Thorough peer review

- No space constraints or color figure charges

- Immediate publication on acceptance

- Inclusion in PubMed, CAS, Scopus and Google Scholar

- Research which is freely available for redistribution 